\title{
Mathematical and computational modeling of the role of homocysteine in the oxidative process and its influence in neuronal degenerative diseases
}

\section{Modelagem matemática e computacional do papel da homocisteína no processo oxidativo e sua influência em doenças degenerativas neuronais}

\author{
Ana Gabriela da Silva Freitas ${ }^{1}$; Gizelle Kupac Vianna ${ }^{2}$; \\ Claudia Mazza Dias ${ }^{3}$
}

\begin{abstract}
Degenerative neurological diseases, although common in the population, are difficult to diagnose. However, it is known that most of them are directly related to the so-called oxidative stress. Understanding and evaluating how this process takes place is of great interest and, in this sense, this work extends the existing mathematical and computational models for the oxidative stress process (REIS, 2005; REIS et al., 2006; VIANNA, 2005; VIANNA; REIS; CARVALHO, 2012), incorporating an aspect not previously evaluated, the influence of homocysteine indices on the oxidants present in this process. The results indicate that hyperhomocysteinemia can in fact cause oxidative stress and consequent neuronal death, leading to the appearance of neurodegenerative diseases.
\end{abstract}

Keywords: Mathematical neuroscience. Mathematical modeling. Oxidative process. Degenerative diseases.

\section{Resumo}

As doenças neurológicas degenerativas, embora frequentes na população, são de difícil diagnóstico. No entanto, sabe-se que grande parte delas tem relação direta com o chamado estresse oxidativo. Entender e avaliar como se dá este processo é de grande interesse e nesse sentido este trabalho estende os modelos matemáticos e computacionais existentes para o processo de estresse oxidativo (REIS, 2005; REIS et al., 2006; VIANNA, 2005; VIANNA; REIS; CARVALHO, 2012), incorporando um aspecto até então não avaliado, a influência dos índices de homocisteína nos oxidantes presentes neste processo. Os resultados indicam que a hiperhomocisteinemia pode de fato causar o estresse oxidativo e consequente morte neuronal, levando ao aparecimento de doenças neurodegenerativas.

Palavras-chave: Neurociência matemática. Modelagem matemática. Processo oxidativo. Doenças degenerativas.

\footnotetext{
${ }^{1}$ Master, PPGMMC, UFRRJ, Seropédica, RJ, Brazil, E-mail: anagfreitas93@gmail.com

2 Profa. Dr., Dept of Computing, UFRRJ, Seropédica, RJ, Brazil, E-mail: gkupac@ gmail.com

${ }^{3}$ Profa. Dr., PPGMMC, UFRRJ, Nova Iguaçu, RJ, Brazil, E-mail: mazzaclaudia@ gmail.com
} 


\section{Introduction}

Degenerative neurological diseases, although common in the population, are difficult to diagnose. For each disease, there is a distinct pathological mechanism and clinical course, which makes its differentiation not always a simple task making the diagnosis often late (OLIVEIRA, 2019). Understanding and evaluating how this process takes place is of great interest and in this sense, the use of mathematical and computational modeling can be configured as an interesting tool for studying the process. However, it is known that most of them are directly related to the so-called oxidative stress (OS). Oxidative stress is characterized by an imbalance in the relationship between the oxidant system and the body's antioxidant defenses. In excess, oxidants damage lipids, proteins and other molecules important for cell function (LOBO et al., 2010).

The work of Duch (2007) presents a interesting review of computational models for dementia and neurological problems. He concludes that "simple neural models based on small number of assumptions allow for qualitative understanding of experimental observations in neuroscience and may help to generate interesting ideas for new experiments. Biophysical models capture sufficient amount of details to answer in silico precise questions that may be very difficult to answer experimentally". According to Cutsuridis and Moustafa (2017), although most studies have made efforts to model the OS process, the existing models do not explain the relationship between neural changes with $\beta$ Amyloid, for example Moustafa et al. (2010). The authors discuss biochemical, single cell, biophysical spiking, and systems-level and abstract models of Alzheimer's disease. The work of Rowan, Neymotim and Lytton (2014), presents a model based on a mechanistic explanation of how targeted brain stimulation can slow the progression of Alzheimer's disease. Bianchi et al. (2014) proposes that the use of therapies based on Cyclic-AMP response element-binding protein (CREB) could provide a new approach for the treatment of Alzheimer's disease. The work of Sasidharakurup and Diwakar (2020) presents an extension of the current modeling studies on glutamate excitotoxicity mediated by $\mathrm{TNF} \alpha$ and neuroinflammation, and also a computational model to analyze the TNF $\alpha$ signaling pathway, because inflammation, OS and insulin resistance are related to the development of neurodegenerative diseases. The most comprehensive studies found on how $\beta$ Amyloid causes OS from inflammation leading to neural death were published by Reis (2005), Reis et al.
(2006), Vianna (2005) and Vianna, Reis and Carvalho (2012). So this work extends the initial mathematical and computational models for the OS process, incorporating an aspect that has not evaluated, the influence of homocysteine indices on the oxidants present in this process. According to experts, a diet rich in protein, especially red meat and dairy products, can increase blood levels of homocysteine. But many other factors can influence the increase of this substance in the body, including consumption of alcohol, smoking, use of some medications and even genetic factors (GRAVINA-TADDEI et al., 2005). Regardless of its causes, hyperhomocysteinemia, an increase in homocysteine concentrations, is an important and prevalent risk factor in neurodegenerative diseases. Thus, this work incorporates into the equations that model OS the influence of the presence of homocysteine in the body and analyses the process of hyperhomocysteinemia, by comparing the concentrations of oxidants from the increase in homocysteine levels. The results indicate that hyperhomocysteinemia can in fact lead to OS and consequent neuronal death, a fundamental factor for the appearance of neurodegenerative diseases.

\section{The oxidative process}

One of the most important aspects of neuronal death present in neurodegenerative diseases is OS. The work of Reis (2005) and Reis et al. (2006) stands out, which presents a modeling proposal for OS, based on the premise that this would be the factor responsible for the onset of the dysfunction and consequent neuronal death. OS contributes not only to the onset but also to the progression of degenerative diseases, especially in the elderly. It can be briefly assumed that the process takes place through the following steps: peptide production, defense cell activation, inflammatory process, oxidative modifications of proteins.

The following section will carefully consider each of these steps and their consequences in relation to the progression of degenerative diseases.

\section{$\beta$ Amyloid's production}

The generation of toxic oxidizing substances, such as superoxide and nitric oxide, during the inflammation process, according to some authors, may be related to cell metabolism (SIQUEIRA, 2016), while others relate it to the brain's immune system response (REIS, 2005). But it is unanimous among the authors that such substances can produce harmful oxidants that cause neuronal death. 
In this sense, the role of $\beta$ Amyloid is very important, as it can initiate the inflammatory process, and even cause neuronal death. The inflammatory process begins with the activation of brain immune cells. Once the defense cells are activated, it can be said that the pathological process begins. The next section, in a compact way, deals with this process.

\section{The inflammatory process}

What characterizes the inflammatory process in neuronal pathologies, is the activation of the glial cells responsible for the defense (SOCHOCKA; DINIZ; LESZEK, 2017). However, this process alone cannot be considered to cause the disease, but part of a chain of damage to healthy cells. According to the same author, glial cells (astrocytes and microglial cells) would be responsible for the inflammatory response to the presence of "foreign" substances, releasing the so-called cytokines that link such cells to neurons. These cytokines are immunomodulators.

Astrocytes are glial cells that makeup $25 \%$ of the total brain volume (SIQUEIRA, 2016). They are dynamic cells that maintain cerebral homeostasis, regulating neurotransmitter systems, the processing of synaptic information, energy metabolism, among other phenomena, and which in this study has a special role in the inflammatory response (BELLAVER, 2015). According to Bellaver (2015, p. 17) “... [during which they release pro-inflammatory cytokines and chemokines to attract leukocytes and increase their proliferation at the site of inflammation]".

Microglial cells are characterized by monitoring the external environment, responding to signs of imbalance in homeostasis. They are therefore detectors, constituting one of the main defense systems of the Central Nervous System (CNS), participating in all its essential functions. They represent about $16 \%$ of the cell population in the brain (SIQUEIRA, 2016).

The cytokines produced are immunomodulators, used by the immune system to influence the CNS, generating important behavioral changes such as the reduction of social interactions, cognitive changes, among others. So that one can conclude its importance with diseases associated with aging. Its production, by the glial cells defined above, can occur exacerbated if activation occurs in response to stimuli.

Oxidants, or reactive oxygen species, have a detrimental effect on cell structural and functional integrity. The body, however, has antioxidant mechanisms that pro- tect us from such damage. The imbalance between the antioxidant system and the concentration of reactive oxygen species, causes OS (SIQUEIRA, 2016), an important factor in the pathogenesis of neurodegenerative diseases (ZHU et al., 2006). In the work proposed by Reis et al. (2006), a model for the OS was presented, which considers the oxidative modifications of proteins. This mathematical model considering $\beta$ Amyloid as the primary cause for the onset of the inflammatory process and the resulting neural death associated with neural diseases.

\section{The role of the homocysteine in the oxidative pro- cess}

Homocysteine (HCT) is an amino acid that participates in the formation of body proteins, it is not obtained directly from the diet, but is derived from the metabolism of methionine, which in turn comes from the diet. With regard to its metabolism, HCT has three main destinations:

1. remethylation - hich enables the regeneration of methionine;

2. transfusion - which originates cysteine;

3. releases into the extracellular environment - such as plasma and urine (CARTEIRO, 2017).

Thus, we have that HCT, which is part of the methionine cycle, also contributes to its own maintenance, since methionine and HCT are precursors to each other. Any type of disorder, at any stage of this metabolism, can cause an increase in the levels of HCT concentration, which is called hyperhomocysteinemia (GRAVINA-TADDEI et al., 2005). When HCT is released into plasma, HCT autooxidation occurs, leading to the formation of homocystine, mixed disulfides, and thiolactoneHCT. During the autooxidation process, oxidants are also produced, such as hydrogen peroxide, superoxide radical, and hydroxyl radical (MATOS, 2003). The auto-oxidation of HCT can also cause irregularities in the antioxidant system, mainly in glutathione peroxidase (GPX) and superoxide dismutase (SOD), leading to increased induction of OS (DEMINICE et al., 2007). The present work intends to verify the effect of HCT on OS and how the levels of this substance are related to brain functions that lead to neural death. Since, hyperhomocysteinemia is influenced by nutritional, hereditary, and medication factors, the production of HCT undergoes external interferences, making the model extremely complex. 


\section{The mathematical model}

Considering $[\mathrm{HCTA}]$ the concentration of $\mathrm{HCT}$ in astrocytes and $[H C T N]$ its concentration on neurons. The equations (1) and (2) describe the modeling proposal for temporal variations $(t)$ for HCT concentrations,

$$
\begin{aligned}
& \frac{d[\text { HCTA }]}{d t}=-n_{1}[\text { HCTA }][R S]-n_{2}[\text { HCTA }][\text { PHA }]+ \\
&-n_{3}[\text { HCTA }][R H A], \\
& \frac{d[\text { HCTN }]}{d t}=-n_{4}[H C T N][R S]-n_{5}[\text { HCTN }][P H N]+ \\
&-n_{6}[\text { HCTN][RHN], }
\end{aligned}
$$

where the parcels $n_{1}[H C T A][R S]$ and $n_{4}[H C T N][R S]$ describe the consumption of HCT concentration by the superoxide radical $(R S)$. The parcels $n_{2}[H C T A][P H A]$ and $n_{5}[H C T N][P H N]$ correspond to the decrease in HCT concentration by hydrogen peroxide in astrocytes and neurons $(P H A)$ and $(P H N)$, respectively. The parcels $n_{3}[H C T A][R H A]$ and $n_{6}[H C][R H N]$ represent the consumption of HCT by the hydroxyl radical in astrocytes and neurons $(R H A)$ and $(R H N)$, respectively.

To verify the effect of HCT on OS the system of equations present in Freitas (2020), Reis (2005) and Reis et al. (2006), formed by about 200 coupled ordinary equations were modified. Thus, the present work, due to space limitations, presents only the new proposals for modeling the variation of substances that are directly involved with the process. The reader can find in Freitas (2020) and Reis (2005) all the details about the system of ordinary differential equations.

As can be seen in equations (1) and (2), HCT increases the levels of oxidants: superoxide radical, hydrogen peroxide, and also hydroxyl radical. Thus, their influence on the equations regarding the variations of these substances in the original model was considered. So the equation (3), considers how HCT, both in astrocytes and neurons, alters the concentration levels of the superoxide radical $[R S]$

$$
\begin{gathered}
\frac{d[R S]}{d t}=n_{7}[M A]+n_{8}[A A]-n_{9}[R S][\text { ON }]-2 n_{10}[R S]+ \\
-2 n_{11}[\text { SODA }][R S]-2 n_{12}[R S]-2 n_{13}[\text { SODN }][R S]+ \\
-n_{14}[R S][\text { COBIA }]-n_{15}[R S][\text { FERIA }]+ \\
-n_{16}[R S][\text { COBIN }]-n_{17}[R S][\text { FERIN }]+ \\
+n_{1}[\text { HCTA }][R S]+n_{4}[\text { HCTN }][R S], \quad \text { (3) }
\end{gathered}
$$

where the parcels $n_{7}[M A]$ and $n_{8}[A A]$, refer to the formation of superoxide radical by microglia and astrocytes.
$[M A]$ is the concentration of the activated microglia and $[A A]$ is the concentration of active astrocytes. The parcel $n_{9}[R S][O N]$ is the formation of peroxynitrite, where $[O N]$ is nitric oxide concentration. Parcels $2 n_{10}[R S]$, $2 n_{11}[R S][S O D A]$ and $2 n_{13}[R S][S O D N]$ describe the formation of hydrogen peroxide, where $[S O D A]$ is the concentration of superoxide dismutase in astrocytes and [SODN] is the concentration of superoxide dismutase in neurons. Finally, the parcels $n_{14}[R S][C O B I A], n_{15}[R S][$ FERIA $]$, $n_{16}[R S][C O B I N]$ and $n_{17}[R S][F E R I N]$ represent the reactivation of metals in the hydroxyl radical formation process, where $[C O B I A]$ and $[F E R I A]$ are the concentrations of copper and iron inactive in astrocytes, and [COBIN] and $[F E R I N]$ are the concentrations of copper and iron inactive in neurons.

Equations (4) and (5) describe the variation in the concentration of hydrogen peroxide in astrocytes and neurons, also to consider homocysteine as a factor that leads to increased concentrations of this oxidant

$$
\begin{aligned}
\frac{d[\text { PHA }]}{d t}=n_{10}[R S]-n_{18}[\text { SODRSA }]+ \\
-2 n_{19}[\text { PHA }][\text { CATA }]-n_{20}[\text { GSHA }][\text { PHA }][\text { GPXA }]+ \\
-n_{21}[\text { NADPHA }][\text { PHA }][\text { TRXA }]+ \\
-n_{22}[\text { COBAA }][\text { PHA }]-n_{23}[\text { PHA }][\text { FERAA }]+ \\
+n_{2}[\text { HCTA }][\text { PHA }],
\end{aligned}
$$

$$
\begin{aligned}
& \frac{d[\text { PHN }]}{d t}=n_{10}[R S]-n_{24}[\text { SODRSN }]+ \\
& -2 n_{25}[\text { PHN }][\text { CATN }]-n_{26}[\text { GSHN }][\text { PHN }][\text { GPXN }]+ \\
& -n_{27}[\text { NADPHN }][\text { PHN }][\text { TRXN }]+ \\
& -n_{28}[\text { COBAN }][\text { PHN }]-n_{29}[\text { PHN }][\text { FERAN }]+ \\
& +n_{5}[\text { HCTN }][\text { PHN }] .
\end{aligned}
$$

In equations (4) and (5) $[P H A]$ is the concentration of hydrogen peroxide in astrocytes and $[P H N]$ in neurons. The parcel $n_{10}[R S]$ represents the formation of hydrogen from superoxide. Parcels $n_{18}$ [SODRSA] and $n_{24}[S O D R S N]$ describe the formation of hydrogen peroxide through superoxide dismutase, where [SODRSA] and $[S O D R S N]$ describe, respectively, the concentration of superoxide dismutase occupied with radical superoxide in astrocytes and neurons. The parcels, $2 n_{19}[P H A][C A T A]$, $n_{20}[G S H A][P H A][G P X A], n_{21}[$ NADPHA][PHA][TRXA], $2 n_{25}[P H N][C A T N], \quad n_{26}[G S H N][P H N][G P X N] \quad$ and $n_{27}[N A D P H N][P H N] \quad[T R X N]$ describe the consumption of hydrogen peroxide through catalase, glutathione peroxidase and thioredoxin reductase. 
We consider that $[C A T A]$ is the concentration of catalase in astrocytes and $[C A T N]$ its concentration on neurons; $[G S H A]$ is the concentration of glutathione in astrocytes and $[G S H N]$ in neurons; $[G P X A]$ is the concentration of glutathione peroxidase in astrocytes and $[G P X N]$ in neurons; $[T R X A]$ is the concentration of thioredoxin in astrocytes and $[T R X N]$ the concentration on neurons; $[N A D P H A]$ and $[N A D P H N]$ are variations in nicotinamide and adenine dinucleotide phosphate concentrations in astrocytes and neurons, respectively. Finally, the parcels $n_{22}[C O B A A][P H A], n_{23}[F E R A A][P H A]$, $n_{28}[C O B A N][P H N]$ and $n_{29}[F E R A N][P H N]$ represent the consumption of hydrogen peroxide by metals for the production of the hydroxyl radical. We define that $[C O B A A]$ is the concentration of active copper in astrocytes and $[C O B A N]$ in neurons; $[F E R A A]$ is the concentration of active iron in astrocytes and $[F E R A N]$ the concentration on neurons.

The equations regarding the influence of HCT on the hydroxyl radical concentrations in astrocytes and neurons are described in (6) and (7), respectively

$$
\begin{aligned}
& \frac{d[R H A]}{d t}=n_{22}[C O B A A][P H A]+n_{23}[F E R A A][P H A]+ \\
& -n_{30}[R H A][G S H A]-n_{31}[R H A][A T A]+ \\
& -n_{32}[R H A][A A A]-n_{33}[R H A][T R X A]+ \\
& -n_{34}[R H A][P R O T A]+ \\
& -n_{35}[R H A][\text { PROT EMPOXA }]+ \\
& -n_{36}[R H A][L H A]+n_{3}[H C T A][R H A],
\end{aligned}
$$

$$
\begin{aligned}
& \frac{d[R H N]}{d t}=n_{28}[C O B A N][P H N]+n_{29}[\text { FERAN }][P H N]+ \\
& -n_{37}[R H N][G S H N]-n_{38}[R H N][A T N]+ \\
& -n_{39}[R H N][A A N]-n_{40}[R H N][T R X N]+ \\
& -n_{41}[R H N][\text { PROTN }]+ \\
& -n_{42}[R H N][\text { PROTEMPOXN }]+ \\
& -n_{43}[R H N][L H N]+n_{6}[H C T N][R H N]
\end{aligned}
$$

where the parcels $n_{22}[C O B A A][P H A], n_{23}[F E R A A][P H A]$, $n_{28}[C O B A N][P H N]$ and $n_{29}[F E R A N][P H N]$ represent the production of hydroxyl radical by hydrogen peroxide with the metals copper and iron. The parcels $n_{30}[R H A][G S H A]$ and $n_{37}[R H N][G S H N]$ represent the elimination of the hydroxyl radical by glutathione; $n_{31}[R H A][A T A]$ and $n_{38}[R H N][A T N]$ describe the elimination of the hydroxyl radical by $\alpha$-tocopherol; $n_{32}[R H A][A A A]$ and
$n_{39}[R H N][A A N]$ show the elimination of the hydroxyl radical by ascorbic acid; $n_{33}[R H A][T R X A]$ and $n_{40}[R H N][T R X N]$ represent the elimination of the hydroxyl radical by thioredoxin. In equations, $[R H A]$ is the concentration of hydroxyl radical in astrocytes and $[R H N]$ in neurons; $[A T A]$ is the concentration of $\alpha$-tocopherol in astrocytes and $[A T N]$ the concentration on neurons; $[A A A]$ is the concentration of ascorbic acid in astrocytes and $[A A N]$ on neurons; $[T R X A]$ is the concentration of thioredoxin in astrocytes and $[T R X A]$ the concentration on neurons; $[G S H A]$ is the concentration of glutathione in astrocytes and $[G S H N]$ on neurons.

In equations (6) and (7) the parcels $n_{34}[R H A][$ PROTA], $n_{35}[R H A][$ PROT EMPOXA $], \quad n_{41}[R H N][$ PROTN $]$, $n_{42}[R H N][$ PROT EMPOXN $]$ describe the reaction of the hydroxyl radical with temporarily oxidized proteins when they are transformed into non-radicals. We consider that [PROTEMPOXA] is the concentration of the temporarily oxidized protein in astrocytes and [PROTEMPOXN] the concentration on neurons; $[$ PROTA $]$ is the concentration of protein in astrocytes and $[P R O T N]$ on neurons. Finally, the parcels $n_{36}[R H A][L H A]$ and $n_{43}[R H N][L H N]$ represent the deactivation of the hydroxyl radical when reacting with a lipid, where $[L H A]$ is the lipid concentration in astrocytes and $[L H N]$ on neurons. The constants $n_{1}$ to $n_{43}$ are positives.

\section{The numerical experiment}

This section presents the results of the simulations performed. The complete model, which includes, in addition to the proposed equations (1)-(7), those found in Freitas (2020) and Reis et al. (2006). The differential ordinary equations system is solved by the Runge-Kutta method of $4^{\text {th }}$ order. For equations (1) and (2) the initial concentration values were considered the lowest values that each substance can admit in a healthy individual based on the literature (CARDOSO, 2009). The other initial concentrations were taken in accordance with Reis (2005). The parameters or rates were admitted empirically, see Table 1.

We will analyze the concentration of oxidants: superoxide radical, hydrogen peroxide, and hydroxyl radical under the influence of HCT at three different concentration levels.

For a first comparative study, we will consider an initial concentration of HCT equal to $10 \mu \mathrm{mol} / \mathrm{L}$. This value is an average of plasma HCT levels for healthy individuals, both male and female (CARDOSO, 2009). 
Table 1 - Values of the parameters adopted in the numerical tests (in $\mu \mathrm{mol} / \mathrm{s}$ )

\begin{tabular}{cl|cl}
\hline Parameter & Value & Parameter & Value \\
\hline$n_{1}$ & $1 \times 10^{-3}$ & $n_{23}$ & $1 \times 10^{-2}$ \\
$n_{2}$ & $1 \times 10^{-3}$ & $n_{24}$ & $2.53 \times 10^{-2}$ \\
$n_{3}$ & $1 \times 10^{-3}$ & $n_{25}$ & $2.53 \times 10^{-3}$ \\
$n_{4}$ & $1 \times 10^{-3}$ & $n_{26}$ & $1.3 \times 10^{-8}$ \\
$n_{5}$ & $1 \times 10^{-3}$ & $n_{27}$ & $2.53 \times 10^{-3}$ \\
$n_{6}$ & $1 \times 10^{-3}$ & $n_{28}$ & $1 \times 10^{-2}$ \\
$n_{7}$ & $5 \times 10^{-1}$ & $n_{29}$ & $1 \times 10^{-2}$ \\
$n_{8}$ & $5 \times 10^{-1}$ & $n_{30}$ & $2 \times 10^{-5}$ \\
$n_{9}$ & $5 \times 10^{-2}$ & $n_{31}$ & $1 \times 10^{-3}$ \\
$n_{10}$ & $4 \times 10^{-1}$ & $n_{32}$ & $1 \times 10^{-3}$ \\
$n_{11}$ & $2.5 \times 10^{-3}$ & $n_{33}$ & $1 \times 10^{-5}$ \\
$n_{12}$ & $4.3 \times 10^{-1}$ & $n_{34}$ & $5 \times 10^{-2}$ \\
$n_{13}$ & $2.5 \times 10^{-3}$ & $n_{35}$ & $1 \times 10^{-2}$ \\
$n_{14}$ & $1 \times 10^{-2}$ & $n_{36}$ & $1 \times 10^{-8}$ \\
$n_{15}$ & $1 \times 10^{-2}$ & $n_{37}$ & $2 \times 10^{-5}$ \\
$n_{16}$ & $1 \times 10^{-2}$ & $n_{38}$ & $1 \times 10^{-3}$ \\
$n_{17}$ & $1 \times 10^{-2}$ & $n_{39}$ & $1 \times 10^{-3}$ \\
$n_{18}$ & $2.5 \times 10^{-2}$ & $n_{40}$ & $1 \times 10^{-4}$ \\
$n_{19}$ & $2.5 \times 10^{-3}$ & $n_{41}$ & $5 \times 10^{-2}$ \\
$n_{20}$ & $1 \times 10^{-8}$ & $n_{42}$ & $1 \times 10^{-2}$ \\
$n_{21}$ & $2.5 \times 10^{-3}$ & $n_{43}$ & $1 \times 10^{-8}$ \\
$n_{22}$ & $1 \times 10^{-2}$ & & \\
\hline & & &
\end{tabular}

Source: The authors.

As expected, due to the HCT values being within the normal range, there are no significant changes in the results of the oxidants when compared to the reference values, Figure 1. Soon after, we changed the initial concentration of HCT to an intermediate value of $50 \mu \mathrm{mol} / \mathrm{L}$ and further increasing the initial HCT concentration to a value of 150 $\mu \mathrm{mol} / \mathrm{L}$, considered high (CARDOSO, 2009).

Analyzing the superoxide radical, for example, we see in Figure 1 the concentration of this oxidant to an initial HCT value equal to $10 \mu \mathrm{mol} / \mathrm{L}$. We can also observe in Figure 1, an increase of 0,03 $\mu \mathrm{mol} / \mathrm{L}$, in the order of $6.3 \%$ at the peak concentration of the superoxide radical, when the initial concentration of $\mathrm{HCT}$ is an intermediate value of $50 \mu \mathrm{mol} / \mathrm{L}$, confirming the behavior described in the literature (AGRAWAL et al. 2015; ANSARI et al., 2014). This variation can be seen in Figure 1. Then, considering the initial concentration of HCT at a severe level of $150 \mu \mathrm{mol} / \mathrm{L}$, again we observed the change in the concentration levels of this oxidant, with an increase of approximately $0,13 \mu \mathrm{mol} / \mathrm{L}, 27.4 \%$ at the peak of the concentration of the superoxide radical. The results corroborate the fact that the high concentration of HCT causes an increase in the concentration of the superoxide radical during OS.
Figure 1 - Superoxide radical concentrations for 10 $\mu \mathrm{mol} / \mathrm{L}, 50 \mu \mathrm{mol} / \mathrm{L}$ and $150 \mu \mathrm{mol} / \mathrm{L}$ of homocysteine.

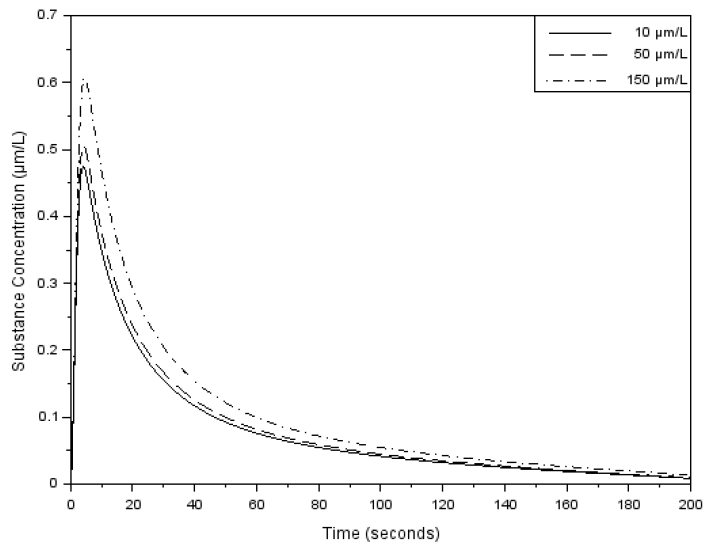

Source: The authors.

We will analyze how HCT influences the concentration of hydrogen peroxide in astrocytes and neurons. Therefore, just as it was done to the superoxide radical, we will start with the HCT concentration value equal to 10 $\mu \mathrm{mol} / \mathrm{L}$. By changing the concentration of HCT to an intermediate value of $50 \mu \mathrm{mol} / \mathrm{L}$, we noticed an increase of approximately $0,12 \mu \mathrm{mol} / \mathrm{L}, 20.6 \%$ at the peak of hydrogen peroxide concentration in astrocytes and an increase of approximately $0,13 \mu \mathrm{mol} / \mathrm{L}, 21.1 \%$ at the peak of hydrogen peroxide concentration in neurons. These variations can be verified in Figure 2 and in Figure 3.

Figure 2 - Hydrogen peroxide concentrations in astrocytes for $10 \mu \mathrm{mol} / \mathrm{L}, 50 \mu \mathrm{mol} / \mathrm{L}$ and $150 \mu \mathrm{mol} / \mathrm{L}$ of homocysteine.

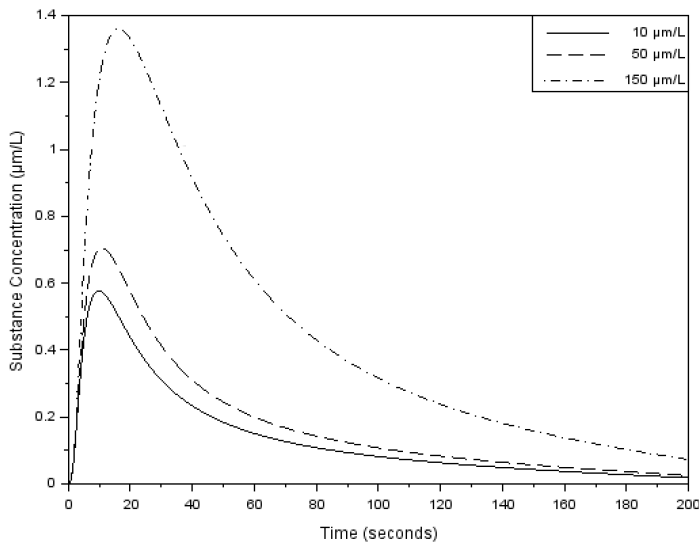

Source: The authors.

Considering the initial concentration of HCT with a severe value of $150 \mu \mathrm{mol} / \mathrm{L}$, we observed again a change in the concentration levels of hydrogen peroxide, this time of approximately $0,78 \mu \mathrm{mol} / \mathrm{L}$ or 134.4 $\%$, in the case of astrocytes and $0,82 \mu \mathrm{mol} / \mathrm{L}, 133.3 \%$ in the case of neurons. The figure 2 describe this variation in astrocytes, and Figure 3 illustrate this variation in neurons. 
Figure 3 - Hydrogen peroxide concentrations in neurons for $10 \mu \mathrm{mol} / \mathrm{L}, 50 \mu \mathrm{mol} / \mathrm{L}$ and $150 \mu \mathrm{mol} / \mathrm{L}$ of homocysteine.

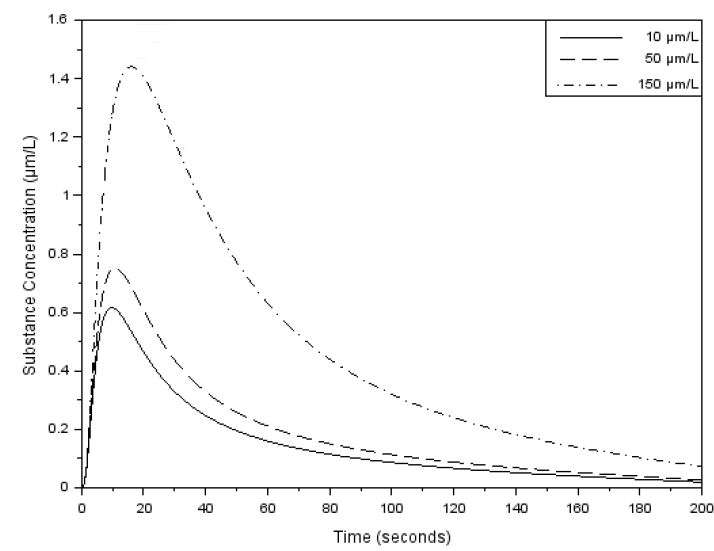

Source: The authors.

Analyzing how HCT influences the concentration of the hydroxyl radical in astrocytes and neurons, we will consider, as before, the initial value of HCT concentration equal to $10 \mu \mathrm{mol} / \mathrm{L}$. Figures 4 and 5 present the concentration levels of the hydroxyl radical in astrocytes and neurons. For an intermediate value of initial HCT concentration of $50 \mu \mathrm{mol} / \mathrm{L}$, we noticed an increase of approximately $0,0013 \mu \mathrm{mol} / \mathrm{L}$ or $32.5 \%$ in the peak hydroxyl radical concentration in astrocytes and an increase of approximately $0,0017 \mu \mathrm{mol} / \mathrm{L}$ or $32.7 \%$ at the peak of hydroxyl radical concentration in neurons. These variations can be verified in Figures 4 and 5 .

Figure 4 - Hydroxyl radical concentrations in astrocytes for $10 \mu \mathrm{mol} / \mathrm{L}, 50 \mu \mathrm{mol} / \mathrm{L}$ and $150 \mu \mathrm{mol} / \mathrm{L}$ of homocysteine.

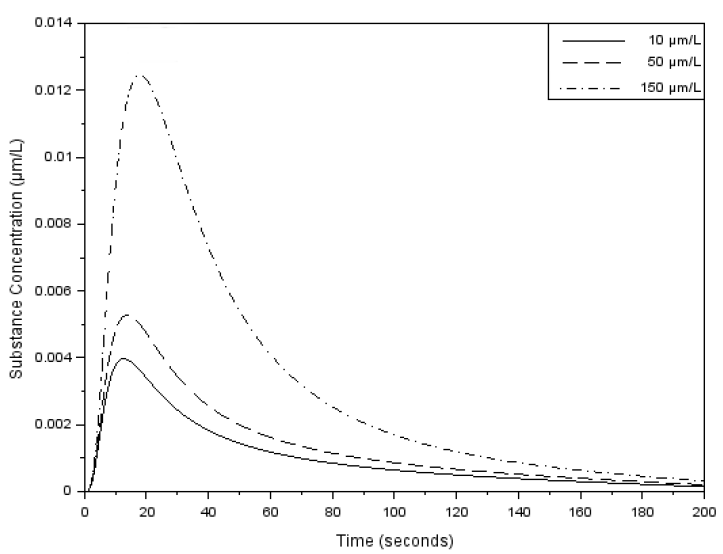

Source: The authors

For an initial HCT concentration of $150 \mu \mathrm{mol} / \mathrm{L}$, we again observed a change in the concentration levels of the hydroxyl radical, where the increase was approximately $0,008 \mu \mathrm{mol} / \mathrm{L}$ or $200 \%$ in astrocytes and $0,01 \mu \mathrm{mol} / \mathrm{L}$ or $192.3 \%$ in neurons. We can verify this variation in Figure 4 which describes the variation in astrocytes, and Figure 5 which describes this variation in neurons.
Figure 5 - Hydroxyl radical concentration in neurons for $10 \mu \mathrm{mol} / \mathrm{L}, 50 \mu \mathrm{mol} / \mathrm{L}$ and $150 \mu \mathrm{mol} / \mathrm{L}$ of homocysteine.

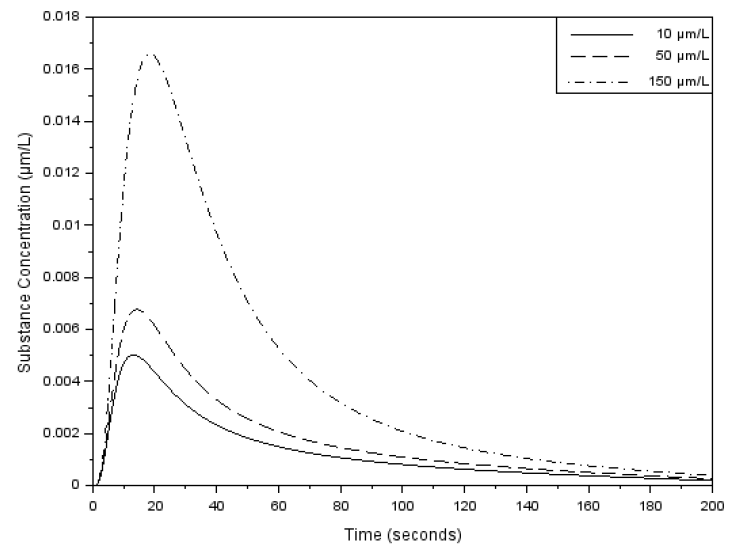

Source: The authors.

Analyzing the three oxidants studied, we can see that HCT has a greater influence on the hydroxyl radical. The least influence being exerted under the superoxide radical which is in line with the medical literature (ŠKOVIEROVÁ et al., 2016).

Due to the increase in oxidation from the $\beta$-amyloid, together with HCT, the levels of antioxidants used fall rapidly, returning to stability as these substances break down. This is because antioxidants will eliminate these harmful substances to the brain in an attempt to maintain normal brain processes (REIS, 2005). One of the main antioxidants that participate in cellular protection is glutathione. We will analyze the consumption of this antioxidant in astrocytes and neurons for HCT levels equal to $10 \mu \mathrm{mol} / \mathrm{L}, 50 \mu \mathrm{mol} / \mathrm{L}$ and $150 \mu \mathrm{mol} / \mathrm{L}$.

For a HCT initial concentration value equal to 10 $\mu \mathrm{mol} / \mathrm{L}$, there are no changes in the production of oxidants and consequently, there is no change in the glutathione cycle. As for the level of concentration equal $50 \mu \mathrm{mol} / \mathrm{L}$, where we notice an increase in the levels of oxidants, glutathione undergoes a small change when stabilizing the concentration levels. Finally, for the value of $150 \mu \mathrm{mol} / \mathrm{L}$, glutathione undergoes a more significant change in the stabilization process. This comparison is illustrated through the Figures 6 and 7. We emphasize that as some parameter values used in the analyzes were adopted empirically, the results indicate qualitative changes in the concentrations. However, this condition does not invalidate the analyzes that indicate the behavior of the concentrations over time and the influences suffered by the introduction of high levels of HCT in the system. For reproducibility purposes, the reader will find the complete model as well as the initial parameters and conditions in $/ \mathrm{hspace} 4.1 \mathrm{~cm}$ (FREITAS, 2020). 
Figure 6 - Glutathione concentration in astrocytes for 10 $\mu \mathrm{mol} / \mathrm{L}, 50 \mu \mathrm{mol} / \mathrm{L}$ and $150 \mu \mathrm{mol} / \mathrm{L}$ of homocysteine.

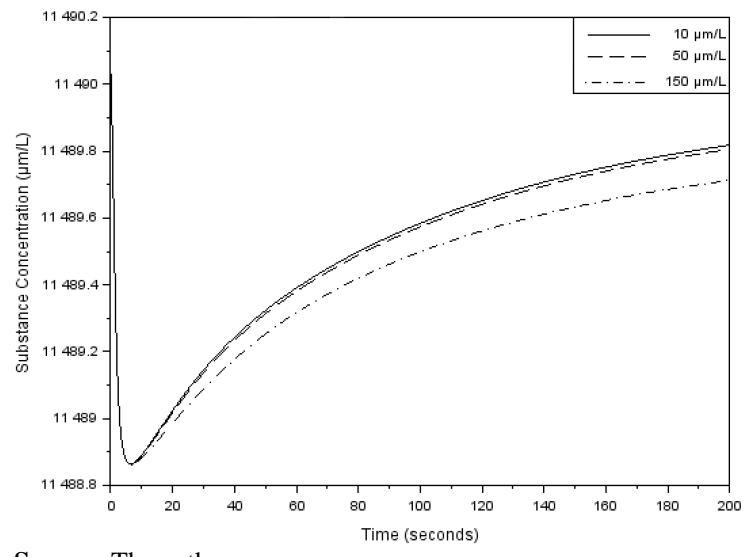

Source: The authors.

Figure 7 - Glutathione concentration in neurons for 10 $\mu \mathrm{mol} / \mathrm{L}, 50 \mu \mathrm{mol} / \mathrm{L}$ and $150 \mu \mathrm{mol} / \mathrm{L}$ of homocysteine.

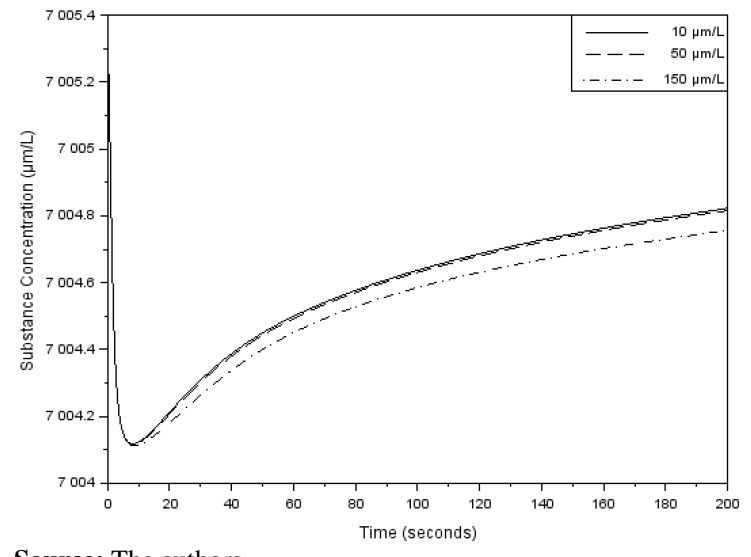

Source: The authors.

\section{Conclusions}

Neurodegenerative diseases are incurable and debilitating diseases, a consequence of progressive degeneration and/or death of neurons, which affect movement and loss of cognitive functions. Many of these diseases are related to OS, where excess oxidants can cause damage to neurons, promoting neurodegeneration. Within this context, the present work presents the influence of HCT levels on the following oxidants: superoxide radical, hydrogen peroxide, and hydroxyl radical. In the analysis of the results, it was possible to notice that the influence of HCT on oxidants becomes clearer for values above 100 $\mu \mathrm{mol} / \mathrm{L}$.

The hydroxyl radical, which is one of the most harmful substances for neural survival, as it is extremely reactive, was the oxidant that suffered the most changes, possibly because its production depends on hydrogen peroxide, which increases significantly with the influence of HCT, in addition to the increase that HCT itself causes in the hydroxyl radical.
Glutathione is one of the main antioxidants that act in the defense of cells against oxidative stress. With the introduction of HCT in the model, the glutathione cycle underwent changes causing a delay in its stabilization. This is because with a greater excess of oxidants, due to the addition of HCT, glutathione will have a greater work to eliminate these harmful substances to the brain, in an attempt to maintain normal brain processes. These changes are clear for concentration levels from $100 \mu \mathrm{mol} / \mathrm{L}$, with a view to increasing the levels of oxidants.

With this analysis, we can see that a low concentration of HCT has little influence on OS. In order to cause significant changes, the levels must be critical, as indicated in the medical literature (AGRAWAL et al., 2015; ANSARI et al., 2014; ŠKOVIEROVÁ et al., 2016).

\section{Acknowledgments}

This study was financed in part by the Coordenação de Aperfeiçoamento de Pessoal de Nível Superior - Brasil (CAPES) - Finance Code 001.

\section{References}

AGRAWAL, A.; ILANGO, K.; SINGH, P. K.; KARMAKAR, D.; SINGH, G. P.; KUMARI, R.; DUBEY, G. P. Age dependent levels of plasma homocysteine and cognitive performance. Behav Brain Res., Amsterdam, v. 283, p. 139-44, 2015. DOI: https://doi.org/10.1016/j.bbr.2015.01.016.

AMORIM, F.; REZENDE, L. C. D.; COITINHO, L.; FREITAS, J. V. Bioquímica clínica da aterosclerose provocada por hiperhomocisteinemia. Revista Eletrônica de Farmácia, Goiânia, v. 3, n. 1, p. 36-59, 2011.

ANSARI, R.; MAHTA, A.; MALLACK, E.; LUO, J. J. Hyperhomocysteinemia and neurologic disorders: a review. Journal of clinical neurology, Mumbai, v. 10, n. 4, p. 281-288, 2014. DOI: http://dx.doi.org/10.3988/jen.2014.10.4.281.

\section{BELLAVER, B. O papel dos astrócitos no envelhecimento} cerebral: avaliação de parâmetros glutamatérgicos, oxidativos e inflamatórios em culturas hipocampais de ratos Wiatai. 2015. Dissertação (Mestrado) - Instituto de Ciências Básicas e de Saúde, Universidade Federal do Rio Grande do Sul, Porto Alegre, 2015. 
BIANCHI, D.; DE MICHELE, P.; MARCHETTI, C.; TIROZZI, B.; CUOMO, S.; MARIE, H.; MIGLIORI, M. Effects of increasing CREB-dependent transcription on the storage and recall processes in a hippocampal CA1 microcircuit. Hippocampus, New York, v. 24, n. 2, p. 165-77, 2014.

CARDOSO, I. L. Homocisteína e doença cardiovascular. Revista da Faculdade de Ciências da Saúde, [S. l.], v. 6, p. 198-206, 2009.

CARTEIRO, J. M. R. Doença de Alzheimer e homocisteína: a dieta mediterrânica como possível fator modificador. 2017. Dissertação (Mestrado) - Faculdade de Medicina da Universidade de Coimbra, Coimbra, 2017.

CUTSURIDIS, V.; MOUSTAFA, A. Computational models of Alzheimer's disease. Scholarpedia, San Diego, v. 12, n. 1, p. 32144, 2017. DOI: 10.4249/scholarpedia.32144.

DEMINICE, R.; VILHENA, R.; PORTARI G. V.; JORDÃO, A. A. Suplementação de creatina, homocisteína e estresse oxidativo. Revista Medicina Ribeirão Preto, Ribeirão Preto, v. 30, n. 3, p. 368-377, 2007.

DUCH, W. Computational models of dementia and neurological problems. In: CRASTO, C. J. (ed.). Methods in Molecular Biology. Totowa: Humana Press, 2007. (J. Walker, series ed.). p. 307-336.

FREITAS, A. G. S. Um Modelo Matemático para o Estresse Oxidativo no Desenvolvimento de Doenças Neurológicas. Dissertação (Mestrado) - Programa de Pósgraduação em Modelagem Matemática e Computacional, Universidade Federal Rural do Rio de Janeiro, 2020.

GRAVINA-TADDEI， C. F.; BATLOUNI, M.; SARTESCHI, C.; BALTAR, V. T.; SALVARINI, N. A. C.; BERTOLAMI, M. C.; SOUSA, J. E. M. R. Hiper-homocisteinemia como fator de risco para doença aterosclerótica coronariana em idoso. Arquivos Brasileiros de Cardiologia, São Paulo, v. 85, n. 3, p. 166-173, 2005.

LOBO, V.; PATIL, A.; PHATAK, A.; CHANDRA, N. Free radicals, antioxidants and functional foods: impact on human health. Pharmacogn Ver, Mumbai, v. 4, n. 8, p. 118-126, 2010.

MATOS, H. C. A homocisteína e sua correlação com doenças cardiovasculares. 2003. Monografia (Especialização Ciências Biológicas) - Centro Universitário De Brasília, Brasília, 2003.
MOUSTAFA, A. A.; KERI, S.; HERZALLA, M. M.; MYERS, C. E.; GLUCK, M. A. A neural model of hippocampal-striatal interactions in associative learning and transfer generalization in various neurological and psychiatric patients. Brain Cogn., New York, v. 74, n. 2, p. $132-134,2010$.

OLIVEIRA, C. A. R. Influência de contaminantes ambientais na patogênese de doenças neurodegenerativas. 2019. Dissertação (Mestrado) - Faculdade de Medicina, Universidade da Beira Interior, Covilhã, 2019.

REIS, A. E. S. Um modelo matemático-computacional do estresse oxidativo na doença de Alzheimer. 2005. Dissertação (Mestrado) - Universidade Federal do Rio de Janeiro, Rio de Janeiro, 2005.

REIS, A. E. S.; VIANNA, G. K.; BARRETO, F.; CARVALHO, L. A. V. A. Computational mathematical model of neuronal death caused by oxidative stress in Alzheimer's disease. Lecture Notes in Computer Science, Berlin, v. 3991, n. 1, p. 842-845, 2006.

ROWAN, M. S.; NEYMOTIM, S.; LYTTON, W. W. Electrostimulation to reduce synaptic scaling driven progression of Alzheimer's disease. Frontiers in computational neuroscience, Lausanne, v. 8, n. 39, p. 1-12, 2014.

SASIDHARAKURUP, H.; DIWAKAR, S. Computational modelling of TNF $\alpha$ related pathways regulated by neuroinflammation, oxidative stress and insulin resistance in neurodegeneration. Applied network Science, [Basel], v. 5, n. 72 , p. 1-21, 2020.

SIQUEIRA, L. D. Estudo dos mecanismos de déficit cognitivo associado ao envelhecimento: o papel da resposta inflamatória. 2016. Dissertação (Mestrado) - Fundação Oswaldo Cruz, Rio de Janeiro, 2016.

SOCHOCKA, M.; DINIZ, B. S.; LESZEK, J. Inflammatory response in the CNS: friend or foe. Molecular neurobiology, Clifton, v. 54, n. 10, p. 8071-8089, 2017.

ŠKOVIEROVÁ, H.; VIDOMANOVÁ, E.; MAHMOOD, S.; SOPKOVÁ, J.; DRGOVÁ, A.; CERVENOVÁ, T.; HA LASOVÁ, E.; LEHOTSKÝ, J. The molecular and cellular effect of homocysteine metabolism imbalance on human health. International Journal of Molecular Sciences, Basel, v. 17, n. 10, p. 1733, 2016.

VIANNA, G. K. Um modelo neurocomputacional do papel do colesterol no desenvolvimento da doença de Alzheimer. 2005. Tese (Doutorado) - Universidade Federal do Rio de Janeiro, Rio de Janeiro, 2005. 
VIANNA, G. K.; REIS, A. E. S.; CARVAlHO, L. A. V. ZHU, X.; PERRY, G.; MOREIRA, P. I., ALIEV, G., Neurociência computacional: um enfoque matemático so- CASH, A. D., HIRAI, K., SMITH, M. A. Mitochondrial bre a doença de Alzheimer. In: ESPERIDIÃO-ANTONIO, abnormalities and oxidative imbalance in Alzheimer disV. Neurociências: diálogos e interseções. Rio de Janeiro: ease. Journal of Alzheimer's Disease, Amsterdam, v. 9, Editora Rubio Ltda, 2012. p. 553-574. n. 2, p. 147- 153, 2006.

YAN, S. D.; ZHU, H.; FU, J.; YAN, S. F.; ROHER, A.; TOURTELLOTE, W. W.; RAJAVASHISTH, T.; CHEN, X.; GODMAN, G. C.; STERN, D.; SCHMIDT, A. M. Amyloid-beta peptide - receptor for advanced glycation end product interaction elicits neuronal expression of macrophage-colony stimulating factor: a proinflammatory pathway in Alzheimer's disease. Proceedings of the National Academy of Sciences of the USA, Washington, v. 94, p. 5296- 5301, 1997. 